\title{
PENGELOLAAN SAMPAH BERBASIS COLLABORATIVE GOVERNANCE DI KOTA TARAKAN PROVINSI KALIMANTAN UTARA
}

\author{
Oleh \\ Djogeh Harmana ${ }^{1}$, \\ Ella L. Wargadinata ${ }^{2}$, Ismail Nurdin ${ }^{3}$ \\ 1) Institut Pemerintahan Dalam Negeri \\ Program Magister Terapan Studi Pemerintahan Daerah Institut Pemerintahan Dalam Negeri \\ harmanapratama@gmail.com \\ ${ }^{2,3)}$ Institut Pemerintahan Dalam Negeri
}

\begin{abstract}
“WASTE MANAGEMENT BASED ON COLLABORATIVE GOVERNANCE IN TARAKAN CITY, NORTH KALIMANTAN PROVINCE"

This study aims to analyze collaborative governance -based waste management and also to 1 analyze the role of each stakeholder in collaborative governance -based waste management in Tarakan City. This study uses a qualitative method with a sampling technique using a snowball sampling technique to obtain a detailed understanding of existing environmental problems. The results of this study explain that there are still shortcomings in the cooperative relationship between the government and the private sector, because the private sector only provides assistance without any other participation by the private sector. In addition, community participation in waste management is also felt to be very lacking because even though a program has been made to manage waste, there are still people from the community who throw garbage indiscriminately in accordance with existing regulations. Efforts are needed from the Tarakan City Environment Office as the coordinator in waste management to increase participation from the community and the private sector.
\end{abstract}

Keywords: garbage, collaboration, participation

\begin{abstract}
ABSTRAK
$\mathrm{P}$ enelitian ini bertujuan untuk menganalisis pengelolaan sampah berbasis collaborative governance dan juga untuk menganalisis terhadap peran masing-masing stakeholder pengelolaan sampah berbasis collaborative governance di Kota Tarakan. Penelitian ini menggunakan metode kualitatif dengan teknik pengambilan sampel menggunakan teknik snowball sampling untuk mendapatkan suatu pemahaman yang mendetail tentang permasalahan lingkungan yang ada. Hasil penelitian ini menjelaskan bahwa masih terdapat kekurangan dalam hubungan kerja sama antara pihak pemerintah dengan pihak swasta, karena pihak swasta hanya memberikan bantuan tanpa adanya partisipasi lain yang dilakukan oleh pihak swasta. Selain itu, partisipasi masyarakat dalam melakukan pengelolaan sampah juga dirasa masih sangat kurang karena walaupun telah dibuat sebuah program untuk mengelola sampah tetapi masih ada saja dari pihak masyarakat yang membuang sampah sembarangan tidak sesuai dengan peraturan yang telah ada. Diperlukan upaya dari Dinas Lingkungan Hidup
\end{abstract}


Kota Tarakan selaku koordinator dalam pengelolaan sampah untuk dapat meningkatkan partisipasi dari pihak masyarakat maupun pihak swasta.

Kata kunci: sampah, kolaborasi, partisipasi

\section{PENDAHULUAN}

Sampah menjadi masalah utama yang Sharus dihadapi oleh daerah, baik itu di kota besar maupun di kota kecil. Kebersihan daerah dari sampah serta pelayanan pengelolaan sampah, oleh pemerintah merupakan salah satu pembenahan utama yang harus dihadapi oleh pemerintah daerah. Bertambahnya jumlah penduduk dan semakin meningkatnya aktivitas masyarakat serta pemerintah dalam suatu pembangunan, merupakan salah satu masalah dalam lingkungan khususnya yang berkaitan dengan meningkatnya produksi sampah.

Sampah merupakan permasalahan yang cukup rumit dihadapi oleh pemerintah dan masyarakat. Pengelolaan sampah harus dijalankan dan dikolaborasikan oleh semua pihak, baik itu masyarakat, pemerintah, kelompok organisasi masyarakat maupun swasta. Pengelolaan sampah harus dilaksanakan dengan penuh tanggung jawab, agar tidak menimbulkan masalah lingkungan yang berdampak terhadap masyarakat maupun pemerintah.

Beberapa upaya yang dilakukan salah satunya adalah dengan membuat inovasi, serta memikirkan bagaimana cara menyelesaikan permasalahan pengelolaan sampah, agar masalah tersebut dapat ditangani dengan mudah dan lebih efektif serta efisien

Pengelolaan sampah secara khusus diatur dalam UU No. 18 Tahun 2018, menjelaskan bahwa pengelolaan sampah diperlukan untuk meningkatkan kesehatan masyarakat dan kualitas lingkungan. Pernyataan tersebut menunjukkan bahwa sampah menimbulkan penurunan kualitas lingkungan, bahkan menjadi ancaman bagi kesehatan. Greenpeace menyatakan bahwa produksi sampah di Indonesia mencapai 65 juta ton per tahun, 10,4 juta ton atau 16 persen merupakan sampah plastik. Total sampah 10,4 juta ton, hanya 1 juta ton atau sekitar 9 persen mengalami proses daur ulang, sekitar 1,2 juta ton atau sekitar 12 persen dibakar. Sampah sebanyak 8,2 juta ton atau 79 persen sampah plastik berakhir begitu saja di TPA maupun tempat umum seperti pantai (Kompas, 21 Feb 2020).

Tanggal 21 Februari diperingati sebagai Hari Perduli Sampah, disebutkan bahwa Indonesia adalah penyumbang sampah plastik kedua terbesar di dunia. Fakta tersebut ini menunjukkan bahwa penanganan sampah di level nasionaldaerah harus menjadi prioritas karena akan berdampak di skala global.

Sampah juga mengancam kesehatan, beberapa penyakit yang berhubungan dengan kebersihan lingkungan masih menjadi penyakit yang menimbulkan korban jiwa di Indonesia. Sampah yang menumpuk dapat menimbulkan berbagai jenis penyakit. Keberadaan bibit penyakit di dalam sampah biasanya berasal dari tercemarnya sampah oleh feses (kotoran) manusia maupun ternak, atau karena sektor serangga pembawa penyakit yang bersarang di dalamnya. Sampah bisa menjadi sumber penyakit, baik secara langsung maupun tidak langsung. Secara langsung, sampah merupakan tempat berkembangnya berbagai parasit, bakteri dan patogen. Secara tidak langsung, sampah merupakan sarang berbagai vector (pembawa penyakit) seperti tikus, kecoa, lalat, nyamuk, dan mencemari sumber air bersih untuk konsumsi. Sampah yang tercemar feses manusia atau ternak dapat menjadi sumber penyakit menular atau sumber patogen yang terdiri atas bakteri, virus, protozoa, dan cacing. Penyakit yang berhubungan dengan 
pola pembuangan sampah yang tidak benar seperti penyakit disentri, diare, kolera, tifus, hepatitis (Medikastar, 27 Feb 2019). Tugas pemerintah dalam pengelolaan sampah sangat penting, misalnya seperti mengeluarkan kebijakan atau peraturan yang bertujuan untuk membagi tugas dan tanggung jawab antara masyarakat maupun pemerintah, dalam pengelolaan masalah sampah. Pemerintah Daerah Melaksanakan tugas tersebut dengan mengeluarkan kebijakan atau peraturan yang menjelaskan apa saja tugas pemerintah dan masyarakat di dalam pengelolaan sampah secara terperinci.

Penduduk Kota Tarakan berjumlah 231.013 jiwa pada 2019 dan memiliki luas wilayah 251.81. Kepadatan penduduk 1008 jiwa/, dan akan terus bertambah dari tahun ke tahun dengan jumlah penduduk yang semakin padat. Dapat dibuktikan dengan tingginya laju pertumbuhan penduduk yang mencapai 3,62 \% per tahun, menurut perhitungan Annual Population Growth Rate (\%) (BPS "Kota Tarakan dalam angka", Proyeksi penduduk Kota Tarakan 20102020). Jumlah penduduk yang bertambah akan berdampak pada peningkatan jumlah sampah yang dihasilkan setiap harinya.

Produksi sampah yang cukup meningkat di Kota Tarakan mendorong pemerintah Kota untuk selalu berinovasi. Volume sampah di Kota Tarakan terus bertambah seiring dengan aktivitas dan dinamika kehidupan masyarakat. TPA Hakebabu mencatat pertambahan sampah sebagai berikut: Tahun 2018, sebanyak 117 ton per hari, tahun 2019 menjadi 127 sampai 130 ton per hari, meningkat sekitar 10 ton per hari dalam setahunnya. Sampah yang masuk ke TPA Hakebabu 60\% merupakan sampah organik, dan selebihnya nonorganik (Radar Kaltara, 8 Oktober 2019). Luas TPA Hakebabu hanya 3 hektar dan tidak mampu menampung seluruh sampah yang diproduksi Kota Tarakan. Penambahan volume sampah membutuhkan lahan TPA yang lebih luas atau melakukan upaya lain dengan mengurangi produksi sampah melalui sistem 3R.

Program pengelolalan sampah "Semesta" adalah salah satu yang diciptakan Kota Tarakan. Program lainnya adalah mengurangi beban sampah di TPA dengan cara melakukan sistem 3R, reduce, reuse, recycle di tingkat TPS. Pada 2020, Kota Tarakan memiliki delapan TPS 3R di Kelurahan: Kampungempat, Kampungenam, Karanganyar, Pantaijuata, Sebengkok, Pamusian (Tribunnews, 15 Januari 2020). Kota Tarakan adalah wilayah pesisir yang memerlukan sistem pengelolaan sampah yang sesuai dengan karakteristiknya. Hasil penelitian juga menunjukkan bahwa perlu sosialisasi yang intens dari pemerintah terhadap masyarakat untuk berpartisipasi aktif dalam pengelolaan sampah

Kota Tarakan sebagai salah satu Kota di Kalimantan Utara yang gagal dalam mempertahankan penghargaan piala adipura. Penghargaan tersebut diraih pada 2006, 2007, 2008, 2009, 2010, 2012 dan 2013. Namun pada 2014 hingga 2019 Kota Tarakan tidak lagi memperoleh Penghargaan Adipura tersebut. TPA yang sudah tidak sanggup menampung produksi sampah warga menjadi salah satu penilaian yang membuat penghargaan lingkungan tersebut menjauh. Sistem pengelolaan sampah di TPA yang menggunakan cara konvensional dengan open dumping menyebabkan daya tampung TPA semakin menyusut.

Bukan hanya masalah TPA, kebiasaan warga membuang sampah sembarang, menjadi pekerjaan rumah bagi Pemerintah Kota Tarakan (Radar Kaltara, 8 Oktober 2019) masalah lainnya adalah jumlah armada pengangkutan dari rumah-depo-TPA yang minim. Kapasitas angkutan sampah juga tidak memadai, bahwa hanya $60-70$ persen sampah yang dapat terangkut dan terbuang ke TPA, sementara sisanya tersebar di berbagai tempat perlu adanya manajemen 
yang bersifat holistik mulai dari hulu hingga hilir (Samudranesia, 28 Januari 2020). Kegagalan tersebut berbanding terbalik dengan Moto Kota Tarakan, yaitu BAIS (Bersih, Aman, Indah, Sehat dan Sejahtera). pada 2016 Pemerintah Kota Tarakan khususnya di Dinas Lingkungan Hidup, terus berusaha memberikan inovasi terbaru, di mana diharapkan masyarakat bisa bekerja sama dengan pemerintah khususnya dalam mengatasi masalah sampah dengan mendukung program pemerintah Kota Tarakan, yakni Program Sampah "Semesta".

Pemerintahan Kota Tarakan terus berusaha mencari inovasi tentang pengelolaan sampah yang lebih efektif dan efisien. Pemerintah Kota Tarakan juga berinovasi dengan membuat program yang diharapkan mampu memberikan dampak positif dan mampu membantu tugas pemerintah dalam pengelolaan sampah, yakni program Sampah "Semesta" (Semua Mesti Terlibat) yang dituangkan dalam Peraturan Daerah Kota Tarakan No. 5 Tahun 2014 tentang Pengelolaan Sampah.

Sampah "Semesta" telah dijalankan Pemerintah Kota Tarakan sejak 2016. Program sampah "Semesta" ini dinilai lebih memudahkan masyarakat dalam membuang sampah karena mekanisme pengelolaannya yang partisipatif di mana alurnya adalah warga menyimpan sampah di depan rumah masing-masing, kemudian akan dijemput petugas di Lingkungan Rumah Tangga (RT), petugas lingkungan tersebut berasal dari Kelompok Swadaya Masyarakat (KSM) yang ditunjuk untuk menjadi petugas pengangkut sampah di lingkungan dan dibiayai melalui iuran bulanan masyarakat per rumah. Sampah yang dikumpulkan oleh petugas pengangkut sampah menggunakan gerobak yang berasal dari bantuan Dinas Lingkungan Hidup, merupakan Satuan Kerja Perangkat Daerah (SKPD) Kota Tarakan yang menangani permasalahan kebersihan lingkungan dan bantuan dari perusahaan swasta yang berada di Kota Tarakan.
Selanjutnya sampah tersebut dikumpulkan ke Tempat Pembuangan Sementara (TPS) dan disebut juga Depo Transfer. Program Sampah "Semesta" ini bertujuan untuk mengajak setiap lapisan masyarakat untuk dapat berkerja sama dan bertanggung jawab, guna menciptakan lingkungan yang bersih dan asri dalam pengendalian pencemaran lingkungan. Kolaborasi antara pemerintah, masyarakat dan pihak swasta ini dikoordinatori oleh Dinas Lingkungan Hidup (DLH), selaku penyelenggara program sampah "Semesta"

Program sampah semesta membutuhkan peran serta semua stakeholders yang terlibat di dalamnya, kolaborasi antara Dinas Lingkungan Hidup (DLH) sebagai leading sector, serta Kelurahan yang bertanggung jawab untuk menyediakan lahan sebagai depo. Selain kerja sama dengan pihak pemerintahan kelurahan dan desa, dalam upaya pelaksanaan program pengelolaan sampah "Semesta" pemerintah Kota Tarakan juga menjalin kerja sama dengan perusahaanperusahaan baik swasta maupun yang dikelola oleh pemerintah. Hal ini merupakan langkah yang dipilih oleh pemerintah Kota Tarakan supaya lebih mudah dalam melaksanakan program pengelolaan sampah "Semesta".

Selama ini sudah terdapat perusahaan yangmemberikan bantuan berupa kendaraan roda tiga, kendaraan roda dua, gerobak, dan sarana penunjang lainnya (Koran Kaltim, 5 September 2017). Dinas Lingkungan Hidup Kota Tarakan menyampaikan bahwa telah melaksanakan serah terima transfer depo bantuan dari PT Medco EP, PT Pertamina EP, Bank KALTIMKALTARA kepada Pemerintah Kota Tarakan berubah motor tiga roda, gerobak sampah, profil tank airnav, mesin cacah plastik untuk digunakan dalam pelaksanaan program pengelolaan sampah "Semesta".

Beberapa permasalahan yang terjadi dalam pelaksanaan pengelolaan sampah 
program sampah "Semesta” di Kota Tarakan, yakni, terkait dengan waktu atau jadwal dalam membuang sampah rumah tangga untuk dapat di angkut oleh petugas ke TPS, sehingga masih terdapat sampah yang terdapat di lingkungan masyarakat meskipun sampah-sampah sudah diangkut menggunakan gerobak dan dibuang ke TPS oleh petugas pengangkut sampah.

Petugas pengangkut sampah yang tidak bertanggung jawab dalam melaksanakan tugasnya, yaitu ketika melakukan tugas pengangkutan sampah sering tidak tepat waktu atau terlambat tidak sesuai jadwal pengangkutan, sehingga mengakibatkan penumpukan sampah di lingkungan masyarakat, meskipun iuran masyarakat tetap berjalan seperti biasanya sesuai kesepakatan bersama.

Upaya Dinas Lingkungan Hidup dalam menangani permasalahan sampah adalah berkoordinasi dengan pihak kelurahan untuk dapat membantu dan mendukung pelaksanaan program sampah "Semesta" sebagai tindak lanjut kolaborasi antara pemerintah dan masyarakat. Kelurahan melakukan rapat internal bersama Kelompok Swadaya Masyarakat (KSM) membahas terkait permasalahan-permasalahan yang terjadi di lapangan.

\section{METODE PENELITIAN}

Penelitian ini merupakan sebuah penelitian yang menggunakan metode kualitatif dengan teknik analisis data yang dapat dijabarkan menjadi data reduction (reduksi data), data display (penyajian data) serta conclusion drawing (memberikan penyelesaian). Setelah melakukan langkah tersebut maka dilakukan analisis SWOT terhadap data yang diperoleh. SWOT merupakan akronim atau singkatan dari Strengths weakness opportunity threats yang dihadapi Pemerintah dalam Pengelolaan Sampah Berbasis Collaborative Governance di Kota Tarakan Provinsi Kalimantan
Utara. Teknik pengumpulan data yang digunakan adalah observasi, wawancara dan dokumentasi.

\section{HASIL DAN PEMBAHASAN}

\section{Kondisi Awal Proses Collaborative Governance}

\section{- Ketidakseimbangan Kekuatan dan Sumber Daya Antar-Stakeholders}

Dalam penelitian ini, penulis menemukan beberapa kekurangan yang terjadi di dalam kolaborasi antara pemerintah dengan lembaga swasta, apabila mengarah kepada prinsip collaborative governance menurut Chriss Ansell dan Alison Gash. Berdasarkan hasil wawancara dengan Edhy, selaku Kepala Seksi Pengelolaan Sampah Dinas Lingkungan Hidup Kota Tarakan, beliau memberikan tanggapan sebagai berikut.

Kalau kita mau menilik pada siapa sih yang berperan lebih besar, pemerintah atau lembaga swasta dalam kolaborasi ini. Sudah jelas dan dibuktikan dengan fakta di lapangan hasilnya adalah pemerintah. Selama ini pemerintah sudah giat dalam proses implementasi baik perencanaan maupun pengawasan selama dilapangan. Kamiselalu membuat musyawarah di lingkungan masyarakat supaya tahu dan mengerti di mana letak kesalahan dan kekurangan apabila terjadi ketidakpuasan masyarakat terhadap pelayanan yang diberikan. Sedangkan lembaga swasta hanya berkolaborasi dengan cara memberikan bantuan sarana dan prasarana namun belum ada tindak lanjut program apa setelahnya yang akan dilaksanakan, hanya terkesan memberikan bantuan setelah itu selesai.

Kerja sama yang baik antara pemerintah dalam hal ini Dinas Lingkungan Hidup Kota Tarakan dengan lembaga swasta sangat diperlukan dalam proses kolaborasi demi 
terciptanya tujuan bersama yang akan dicapai. Bukan berarti upaya yang dilakukan lembaga swasta dengan memberikan bantuan itu tidak cukup, namun belum tepat apabila dilaksanakan menurut mekanisme kolaborasi.

\section{- Insentif bagi Stakeholders yang Mau Berkolaborasi}

Berdasarkan hasil wawancara dengan Edhy, selaku Kepala Seksi Pengelolaan Sampah Dinas Lingkungan Hidup Kota Tarakan, beliau memberikan tanggapan sebagai berikut.

Sebelum kami mengajak lembaga swasta untuk berkolaborasi dalam proses pengelolaan sampah. Kami telah menyiapkan penghargaan atau pembebasan tertentu kepada lembaga swasta yang bersedia berkolaborasi dengan pemerintah dalam proses pengelolaan sampah. Berdasarkan hasil keputusan pemerintah, akan dikenakan biaya retribusi kepada masyarakat dalam proses sampah semesta ini. Yaitu dikenakan iuran sebesar Rp 5.000,-untuk masyarakat miskin, Rp 15.000,-untuk masyarakat berpenghasilan sedang, dan Rp 20.000,-untuk masyarakat berpenghasilan menengah ke atas yang akan dikenakan setiap bulannya. Hal itu tidak hanya berlaku kepada masyarakat namun juga gedung gedung perkantoran yang pada umumnya dihuni oleh lembaga swasta. Kami memberikan perjanjian kerja kepada mereka barang siapa yang bersedia untuk berkolaborasi dalam memberikan bantuan sarana dan prasarana maka akan dibebaskan iuran kebersihan sampah semesta yang tentu jumlahnya tidak sedikit. Dan inilah bentuk kerja sama yang terjadi antara pemerintah dengan swasta, selain itu kami juga biasanya memasang identitas mereka di sarana dan prasarana yang kami gunakan sebagai bentuk timbal balik dari bantuan mereka kepada pemerintah.
Berdasarkan data yang diperoleh di atas, penulis menyimpulkan bahwa bentuk penghargaan kepada lembaga swasta yang mau berkolaborasi dengan pemerintah sudah terlaksana dengan baik. Walaupun tidak secara langsung dalam bentuk uang, melainkan bentuk kerja sama lainnya yang saling menguntungkan satu sama lain.

\section{- Konflik yang Pernah Terjadi Antar- Stakeholders}

Pada pembahasan kali ini, penulis akan membahas mengenai konflik yang terjadi antara pemerintah yang dalam hal ini adalah Dinas Lingkungan Hidup Kota Tarakan dengan unsur pimpinan dari lembaga swasta. Penulis memberikan fokus kepada unsur pimpinan karena apabila mengacu kepada prinsip collaborative governance menurut Chriss Ansell dan Alison Gash. Maka dalam tahap kondisi awal hanya menitikberatkan kepada peran antar-stakeholder. Berdasarkan hasil wawancara dengan Edhy, selaku Kepala Seksi Pengelolaan Sampah Dinas Lingkungan Hidup Kota Tarakan, beliau memberikan tanggapan berikut ini.

Sejauhproseskolaborasidenganlembaga swasta dalam pengelolaan sampah ini. Belum ada konflik permasalahan yang terjadi. Semua berjalan sesuai rencana dan saling membantu satu sama lain. Hanya saja cukup diberikan kekhawatiran bahwasanya belum ada pembahasan lebih lanjut terkait program apa yang akan dilaksanakan selanjutnya. Apakah hanya berhenti sampai dengan memberikan bantuan atau akan dilaksanakan sistem kerja sama lainnya.

Selain melakukan wawancara dengan unsur pimpinan dari Dinas Lingkungan Hidup Kota Tarakan, penulis juga tidak melupakan kehadiran lembaga swasta. Berdasarkan hasil wawancara dengan Muhammad Junaidi selaku Pelaksana Pembiayaan Bankaltimtara Syariah di Kota Tarakan, beliau beranggapan sebagai berikut. 
Kami sebagai unsur di luar pemerintah dalam hal ini mengenai pengelolaan sampah, sangat memiliki kepedulian untuk membantu pemerintah dalam melaksanakan tugas pelayanan sampah. Kami telah menerima permohonan kerja sama dari Dinas Lingkungan Hidup Kota Tarakan dan telah kami berikan bantuan berupa sarana dan prasarana yang menunjang proses pengelolaan sampah di lapangan. Seperti gerobak, armada, sekop, cangkul dan lain sebagainya. Sebagai tenaga bantuan kami tentunya juga berharap agar keikutsertaan kami tidak berhenti sampai di sini saja. Mungkin selanjutnya kami berharap akan dilaksanakan gerakan gerakan masyarakat atau pengumpulan massa untuk kegiatan refreshing ditambah dengan himbauan peduli terhadap sampah sembari mempromosikan produk kami. Sejauh ini belum ada tindak lanjut dari pemerintah akan hal ini.

Berdasarkan data yang dikumpulkan oleh penulis dan telah disampaikan sebelumnya. Penulis berpendapat bahwa program kolaborasi ini sejatinya telah berjalan dengan melibatkan konflik dari kedua pihak, namun belum terlaksana secara kompleks dan baru sedikit program yang terlaksana.

\section{Kepemimpinan Fasilitatif dalam Collaborative Governance}

Pada poin pembahasan ini, penulis perlu mengulas kembali bahwa kepemimpinan yang fasilitatif itu penting dalam hal membangun suatu kolaborasi. Mengingat kembali kutipan teori collaborative governance menurut Ansell and Gash yang mengatakan bahwa kepemimpinan fasilitatif penting untuk menyatukan para pemangku kepentingan dan membuat mereka saling terlibat dalam semangat kolaboratif. Kepemimpinan yang fasilitatif di sini adalah dengan menyediakan mediasi.
Fasilitasi mediasi penting karena mediasi meningkatkan peran intervensi pihak ketiga dalam perincian substantif negosiasi ketika para pemangku kepentingan tidak efektif dalam mengeksplorasi kemungkinan keuntungan. Hal tersebut yang juga diterapkan oleh Dinas Lingkungan Hidup Kota Tarakan dalam membangun fasilitasi mediasi. Berdasarkan data yang diperoleh di lapangan, penulis membagi ke dalam dua arah. Yaitu antara pemerintah dengan lembaga swasta, dan pemerintah dengan masyarakat.

\section{- Fasilitasi MediasiantaraPemerintah dengan Lembaga Swasta}

Dalam pembahasan ini, penulis memfokuskan pembahasan pada mediasi antara pemerintah dengan lembaga swasta. Berdasarkan hasil wawancara dengan Edhy, selaku Kepala Seksi Pengelolaan Sampah, beliau menanggapi hal tersebut:

Kalau bicara tentang kolaborasi, pemerintah tentu harus sering melakukan pertemuan dengan lembaga swasta di sana (pimpinan lembaga swasta). Sejauh ini pertemuan yang dilakukan sebatas perjanjian kerja atau kontrak kerja sama untuk pengadaan fasilitas sarana dan prasarana. Apabila kita berorientasi pada hasil, pemerintah akan lebih meningkatkan relasi dengan masyarakat. Kami telah menerima saran dari mereka (lembaga swasta) untuk melakukan suatu gerakan masyarakat terkait pengelolaan sampah ini agar tidak berhenti hanya sampai penyediaan fasilitas sarana dan prasarana. Namun pemerintah sedang menyusun rencana untuk melakukan itu, tapi sejauh ini baru sampai hal demikian (kerja sama penyediaan fasilitas sarana dan prasarana)

Berdasarkan hasil wawancara tersebut, penulis menyimpulkan bahwa belum ada tahap mediasi lanjutan antara 
pemerintah dengan lembaga swasta dalam hal pengelolaan sampah. Dan baru sejauh penyediaan fasilitas sarana dan prasarana. Apabila berorientasi kepada teori collaborative governance menurut Ansell and Gash maka kenyataan di lapangan belum berjalan dengan maksimal.

\section{- Fasilitasi Mediasi antara Pemerin- tah dengan Masyarakat}

Dalam pembahasan ini, kajian penulis difokuskan kepada proses mediasi antara pemerintah dengan masyarakat yang sudah berjalan. Melalui teknik wawancara, penulis mengumpulkan dan menyimpulkan data di lapangan dan membandingkannya dengan teori collaborative governance menurut Ansell and Gash. Beberapa pertanyaan terkait fokus kajian telah diberikan oleh penulis. Edhy, selaku Kepala Seksi Pengelolaan Sampah memberikan tanggapan sebagai berikut

Proses kolaborasi yang terjadi antara pemerintah dengan masyarakat sudah berjalan dengan baik. Setiap bulan perwakilan dari Dinas Lingkungan Hidup Kota Tarakan selalu melakukan monitoring di kelurahan kelurahan di Kota Tarakan. Kenapa di kelurahan karena depo pengumpulan sampah di bagi perkelurahan masing-masing. Selain melakukan monitoring, Dinas Lingkungan Hidup Kota Tarakan juga melaksanakan musyawarah dengan masyarakat guna menerima usul dan saran dari mereka dan menerima keluhan masyarakat apabila terjadi kekurangan dalam proses pelayanan. Selain itu pemerintah juga senantiasa memberikan sosialisasi-sosialisasi sederhana agar dapat dipahami oleh masyarakat yang merupakan objek dari pelaksanaan program sampah semesta ini.

Selain menerima data dari Dinas Lingkungan Hidup Kota Tarakan, penulis juga mengambil data dari masyarakat secara langsung agar berita yang disampaikan berstatus konkret dan tidak memihak kepada salah satu pihak. Berdasarkan data yang diambil oleh penulis melalui metode wawancara dengan Suyono selaku kepala RT 09 kelurahan Pamusian, beliau mengatakan:

Masyarakat juga tidak lupa dilibatkan oleh pemerintah dalam hal pengelolaan sampah "Semesta" ini. Mereka (Dinas Lingkungan Hidup Kota Tarakan) juga rutin datang ke setiap kelurahan dengan mengumpulkan tokoh masyarakat seperti ketua RT serta pegawai kelurahan untuk saling menyampaikan keluhan dan saran serta tanggapan terhadap pelayanan yang dilaksanakan. Selain itu mereka juga sering memberikan informasi bagaimana mengelola sampah secara sementara dengan selalu menekankan perilaku 3R (reduce, reuse, recycle) terhadap seluruh masyarakat untuk mengurangi pertumbuhan produksi sampah di lingkungan masyarakat. Melalui upaya ini, pemerintah telah membangun relasi yang baik dengan masyarakat.

Berdasarkan data tersebut, penulis dapat menarik simpulan bahwa pemerintah Kota Tarakan yang dalam hal ini Dinas Lingkungan Hidup Tarakan telah membangun hubungan mediasi yang baik dengan masyarakat, secara rutin dan tertata. Masyarakat merasa tidak dikesampingkan dan hanya menjadi boneka kebijakan namun masyarakat juga dilibatkan langsung dalam pelaksanaan maupun pengawasannya.

Dari kedua data yang ditampilkan sebelumnya, penulis menarik simpulan secara umum bahwa tahap fasilitasi pemerintah yang dikonotasikan ke dalam fasilitasi mediasi baik antara pemerintah dengan lembaga swasta maupun pemerintah dengan masyarakat. Terjadi hal yang tidak seimbang, di mana hubungan mediasi dengan lembaga swasta masih tergolong kurang dan belum adanya kejelasan jangka panjang terkait komitmen yang mereka bangun, sedangkan hubungan mediasi dengan masyarakat sudah berjalan dengan 
sangat baik dan rutin sehingga masyarakat tidak merasa dikesampingkan dalam program pengelolaan sampah "Semesta" ini.

\section{Desain Kelembagaan}

Dalam melaksanakan sebuah program kebijakan sudah dapat dipastikan tentu memiliki dasar atau landasan hukum yang berlaku. Agar tidak terjadi penyalahgunaan wewenang yang dapat memengaruhi orang banyak.Tidaklepas dari program pengelolaan sampah "Semesta" yang diterapkan di Kota Tarakan Provinsi Kalimantan Utara. Penulis mencoba mengkaji beberapa instrumen hukum yang dijadikan sebagai landasan dalam kebijakan tersebut

\section{- Undang-Undang No. 18 Tahun 2008 tentang Pengelolaan Sampah}

Pengelolaan sampah yang dimaksud dalam Undang-Undang No. 18 Tahun 2008 tertera pada Pasal 3 dan 4 yang menyatakan bahwa:

Pada Pasal 3 dijelaskan bahwa pengelolaan sampah diselenggarakan berdasarkan asas tanggung jawab, asas berkelanjutan, asas manfaat, asas keadilan, asas kesadaran, asas kebersamaan, asas keselamatan, asas keamanan, dan asas nilai ekonomi. Selanjutnya pada Pasal 4 dijelaskan pengelolaan sampah bertujuan untuk meningkatkan kesehatan masyarakat dan kualitas lingkungan serta menjadikan sampah sebagai sumber daya.

Dasar peraturan Undang-Undang No. 18 Tahun 2008 tentang pengelolaan sampah pada Pasal 3 dan 4 maka Pemerintah Daerah Kota Tarakan membentuk Dinas Lingkungan Hidup dengan membentuk Peraturan Daerah No. 5 Tahun 2014 tantang Pengelolaan Sampah.

Secara normatif Dinas Lingkungan Hidup Kota Tarakan memang memiliki tugas pokok dan fungsi sebagai sebuah institusi Pemerintahan yang menangani bidang kebersihan lingkungan baik disebabkan oleh faktor alam, non alam dan faktor manusia. Sehingga secara konstitusional sudah sesuai dengan landasan regulasi yang penulis tetapkan.

- Peraturan Pemerintah No. 81 Tahun 2012 tentang Pengelolaan Sampah Rumah Tangga dan Sejenis Sampah Rumah Tangga

Pelaksanaan penelitian yang penulis lakukan dan diperolehlah data yang selanjutnya dianalisis oleh penulis, secara normatif Dinas Lingkungan Hidup Kota Tarakan menangani permasalahan bidang kebersihan yang dalam pelaksanaannya berpatokan pada Peraturan Pemerintah No. 81 Tahun 2012 tentang Pengelolaan Sampah Rumah Tangga dan Sejenis Sampah Rumah Tangga.Sehingga melalui Peraturan Daerah Kota Tarakan No. 5 Tahun 2014 tentang pengelolaan sampah. Pelaksanaan pada pengelolaan sampah khususnya Program Sampah Semesta memiliki lima tahap, yaitu koordinasi, melakukan rapat musyawarah, kegiatan pengangkutan sampah, pengumpulan sampah ditransfer depo, dan penarikan iuran sampah dari tiap masyarakat yang di mana Dinas Lingkungan Hidup Kota Tarakan sudah melaksanakannya yang di mana masing-masing tahap tersebut memiliki prosedur tersendiri yang telah dilaksanakan dalam bidang pengelolaan sampah, data tersebut diperoleh berdasarkan data primer dan wawancara dengan kepala seksi Pengelolaan Sampah Dinas Lingkungan Hidup Kota Tarakan, Edhy, sehingga ada kesesuaian antara landasan normatif dalam penyelenggaraan pengelolaan sampah semesta dengan kondisi di lapangan.

\section{Proses Kolaborasi}

Proses kolaborasi yang terjadi antara pemerintah dengan lembaga swasta adalah langkah awal dalam pelaksanaan program pengelolaan sampah semesta di Kota Tarakan Provinsi Kalimantan Utara. Landasan yang sudah terbentuk ini menjadi penunjang 
dalam proses implementasi di lapangan dengan melibatkan masyarakat sebagai central sector dalam pelaksanaan program sampah semesta ini. Dalam pembahasan ini, yang menjadi fokus penulis adalah hasil kolaborasi yang digambarkan dengan mekanisme pelaksanaan pengelolaan sampah Semesta di Kota Tarakan Provinsi Kalimantan Utara.

Mekanisme merupakan tata laksana yang diterapkan dalam menjalankan suatu program yang telah diterapkan di suatu wilayah agar dapat terlaksana dengan baik dan sesuai dengan prosedur yang telah disepakati. Mekanisme dalam pengelolaan sampah "Semesta" yang diberlakukan di Kota Tarakan Provinsi Kalimantan Utara terdiri dari beberapa tahapan yang dapat dikelompokkan ke dalam beberapa tahap.

1) Sosialisasi kepada masyarakat

2) Tahap pengangkutan sampah

3) Tahap evaluasi dan monitoring

\section{Analisis SWOT Faktor Pendorong dan Penghambat dalam Masalah Sampah}

\section{- Strengths (Kekuatan)}

Kekuatan merupakan salah satu aspek di dalam strategi yang dapat dimanfaatkan untuk mencapai tujuan yang ingin dicapai. Adapun strengths (kekuatan) yang peneliti gunakan merujuk pada Konsep Rangkuti, yaitu analisis SWOT (strengths, weaknesses, opportunities, dan threats). Dalam penelitian mengenai kolaborasi pengelolaan sampah di Kota Tarakan Provinsi Kalimantan Utara berdasarkan fakta di lapangan, terdapat dua subtema dari strengths (kekuatan) yang digunakan oleh peneliti untuk merumuskan dan untuk menyusun pedoman wawancara berdasarkan informan, sub-subtema strengths (kekuatan) diidentifikasikan sebagai berikut.

1) Semangat pemerintah menanggulangi masalah sampah

2) Program "Semesta"

\section{- Weaknesses (Kelemahan)}

Kelemahan dalam suatu organisasi merupakan suatu keterbatasan baik itu berupa keterbatasan Sumber Daya ataupun keterbatasan keterampilan yang akan menghambat kinerja di dalam organisasi. Adapun weaknesses (kelemahan) yang peneliti gunakan merujuk pada Konsep Rangkuti, yaitu analisis SWOT (strengths, weaknesses, opportunities, dan threats). Dalam penelitian mengenai kolaborasi pengelolaan sampah di Kota Tarakan Provinsi Kalimantan Utara berdasarkan fakta di lapangan yang digunakan oleh peneliti untuk merumuskan dan untuk menyusun pedoman wawancara berdasarkan informan yang diidentifikasikan adalah kurangnya sarana dan prasarana.

\section{- Opportunities (Peluang)}

Peluang menurut Sjafrizal (2009: 132) dapat diartikan sebagai "kesempatan dan kemungkinan yang tersedia dan dapat dimanfaatkan untuk mendorong proses pembangunan daerah atau institusi bersangkutan". Adapun opportunities (peluang) yang peneliti gunakan merujuk pada Konsep Rangkuti, yaitu analisis SWOT (strengths, weaknesses, opportunities, dan threats). Dalam penelitian mengenai kolaborasi pengelolaan sampah di Kota Tarakan Provinsi Kalimantan Utara berdasarkan fakta di lapangan, sub-subtema dari opportunities (peluang) yang digunakan oleh peneliti untuk merumuskan tema dan untuk menyusun pedoman wawancara berdasarkan informan yang diidentifikasikan sebagai berikut.

1) Kerja sama dengan swasta

2) Adanya peraturan tentang sampah

\section{- Threats (Ancaman)}

Menurut Sjarizal (2009: 132) ancaman dapat diartikan sebagai suatu kondisi yang datang dari luar dan dapat menimbulkan kesulitan, kendala atau tantangan yang 
cukup serius bagi suatu daerah atau institusi tertentu. Adapun threats (ancaman) yang peneliti gunakan merujuk pada Konsep Rangkuti, yaitu analisis SWOT (strengths, weaknesses, opportunities, dan threats). Dalam penelitian mengenai kolaborasi pengelolaan sampah di Kota Tarakan Provinsi Kalimantan Utara berdasarkan fakta di lapangan, terdapat dua subtema dari threats (ancaman) yang digunakan oleh peneliti untuk merumuskan dan untuk menyusun pedoman wawancara berdasarkan informan yang diidentifikasikan adalah $\mathrm{t}$ i $\mathrm{n} \mathrm{g} \mathrm{k} \mathrm{a} \mathrm{t}$ kedisiplinan petugas pemungut sampah rendah.

\section{SIMPULAN}

Pengelolaan sampah berbasis collaborative governance di Kota Tarakan belum berjalan dengan optimal, disebabkan oleh:

1) Kurangnya kerja sama antara pihak pemerintah dan pihak swasta yang disebabkanoleh perbedaan cara pandang pemerintah dengan pihak swasta dalam hal memperbaiki lingkungan, dalam hal ini pihak swasta hanya memberikan modal dan setelah itu tidak mengetahui hal apa yang akan dilakukan dengan modal tersebut sedangkan pelaksanaan, pengaturan, dan pengawasan dilakukan oleh pihak pemerintah.

2) Rendahnya partisipasi masyarakatdalam pengelolaan sampah yang disebabkan oleh minimnya informasi kepada masyarakat mengenai pengelolaan sampah berbasis collaborative governance.

Faktor internal yang menjadi hambatan dalam pengelolaan sampah berbasis collaborative governance antara lain:

1) Fasilitas gerobak sampah yang masih kurang

2) Kurangnya kapasitas daya tampung TPA
Faktor eksternal yang menjadi hambatan dalam pengelolaan sampah berbasis collaborative governance antara lain:

1) Kurangnya kerja samaantara pemerintah dengan pihak swasta

2) Rendahnya kesadaran masyarakat dalam pengelolaan sampah

3) Rendahnya tingkat kedisiplinan petugas pemungut sampah.

\section{SARAN}

Karena pengelolaan sampah berbasis collaborative governance belum berjalan secara optimal, maka perlu dilakukan:

1) Tingkatkan intensitas komunikasi, baik komunikasi dari pemerintah dengan pihak swasta, maupun komunikasi antara pemerintah dengan masyarakat.

2) Tingkatkan Intensitas integrasi antara pemerintah, pihak swasta dan masyarakat, sehingga tujuan dari pelaksaan program pengelolaan sampah dapat terlaksana dengan baik.

3) Tingkatkan intensitas sinkronisasi antara pemerintah, swasta dan masyarakat, mengingat dalam pelaksanaan kolaborasi, sinkronisasi diperlukan sehingga tercipta kesesuaian dalam pelaksanaan program yang berjalan sesuai dengan tujuan dan peran masing-masing.

4) Tingkatkan intensitas simplifikasi, sehingga dapat menciptakan regulasi terkait pengelolaan sampah yang tertib, sederhana dan proporsional.

Faktor internal yang menjadi penghambat dalam pengelolaan sampah berbasis collaborative governance dapat diatasi dengan:

1) Menambah fasilitas gerobak sampah yang disesuaikan dengan area permukiman dan tempat umum

2) Meningkatkan kapasitas penampungan sampah TPA. 
Faktor eksternal yang menjadi penghambat dalam pengelolaan sampah berbasis collaborative governance dapat diatasi dengan:

1) Meningkatkan kerja sama antara pihak swasta dengan pemerintah dengan meminta partisipasi aktif yang berkelanjutan dari pihak swasta dalam pengelolaan sampah.

2) Melakukan sosialisasi tentang program pengelolaan sampah berbasis collaborative governance kepada masyarakat serta melibatkan masyarakat dalam setiap program pengelolaan sampah.

3) Meningkatkan pengawasan terhadap petugas pemungut sampah

\section{DAFTAR RUJUKAN}

A. Aboejoewono, Pengelolaan Sampah Menuju ke Sanitasi Lingkungan dan Permasalahannya, (Jakarta: Wilayah DKI Jakarta Sebagai Suatu Kasus, 1985).

Abdulsyani, Sosiologi Skematika, Teori, dan Terapan,(Jakarta: Bumi Aksara, 2007), h. 156.

Agranof and McGuire. 2003. Collaborative Public Management. New Strategic for Local Government.

Agus Dwiyanto. 2011. Peduli Inklusif dan kolaborasi. Yogyakarta

Alex S. Sukses Mengolah Sampah Organik Menjadi Pupuk Organik, hlm., 19-23.

Anderson, E.T. \& J. McFarlane, Community as Partner Theory and Practice in Nursing 4th Ed. Philadelphia, 2004

Anderson, E.T. \& J. McFarlane, Community as Partner Theory and Practice in Nursing 4th Ed. Philadelphia, 2004

Andrew B. Whitford, Soo-Young Lee, Taesik Yun \& Chan Su Jung; Collaborative Behavior And The Performance Of Government Agencies, International Public Management Journal, 2010 13: 4, 321-349
Ansell, Chriss \&, Alison Gash (2008). "Collaborative Governance in Theory and Practice". Journal of Public Administration Research and Theory, 18 (4), p 544

Carpenter, Mason. A. \& Sanders, Wm, Gerard, Strategic Management: A Dynamic Prespective, 2nd Edition, (New Jersey: Pearson Printice Hall, 2009)

Chriss Ansell dan Alison Gash. Tata Kelola Pemerintahan dalam Teori dan Praktik. Jurnal Penelitian dan Teori Administrasi Publik. Vol.18, Edisi 4, 1 Oktober 2008, hlm 543-571

Dwiyanto. 2011. Good Governance. Pelayanan Publik. Hal 79-81

Emerson, Kirk, Tina Nabatchi, Stephen Balogh, 2012. "An Integrative Framework for Collaborative Governance". Journal of Public Administration Research and Theory, 22 (1), pp1-29.

Emily R. Lai, Collaborations: A Literature Review, (Pearson, 2011), p. 2.

G. Theisen Tchobanoglous, dan S.A. Vigil, Integrated Solid Waste Management Engineering Principles and Management Issues. hlm.,5-8.

Noorsyamsa Djumara, Negosiasi, Kolaborasi dan Jejaring Kerja. (Jakarta: Lembaga Administrasi Negara-RI, 2008), hh. 34-35

S. Hadiwiyoto, Penanganan dan Pemanfaatan Sampah, (Jakarta: Yayasan Idayu,1983).

Scott London, Collaboration and Community, di unduh dari https: //www.scottlondon. com/reports/collaboration.pdf pada 30 September 2016, p. 2.

Subarsono. 2016. Collaborative governance. 174176

Suryani. Tinjauan Pustaka dan Kerangka Berpikir. https: //www.google.co.id/ url?sa=EktivtasCollaborative-Governance. PTPAS-BAB-II. Diakses pada 2013

Tchobanoglous, George. Theisen, Hilary. Vigil, S. A. 1993 Integrated solid waste management.

Widyatmoko, H., Moerdjoko, S. 2002. Tinjauan Umum Tentang Sampah dan Pengelolaannya. Menghindari, Mengolah dan Menyingkirkan Sampah 
Yudhi Kartikawan, Pengelolaan Persampahan, (Yogyakarta: Jurnal Lingkungan Hidup), 2000

\section{Peraturan Perundang-Undangan}

Undang-Undang No. 18 Tahun 2008 tentang Pengelolaan Sampah.

Peraturan Pemerintah No. 81 Tahun 2012 Pasal 5 tentang Kebijakan Mengenai Pengelolaan Sampah.

Peraturan Pemerintah No. 81 Tahun 2012 Pasal 9 tentang Peran Pemerintah dalam Upaya Pengelolaan Sampah.
Peraturan Daerah Kota Tarakan No. 5 Tahun 2014 Pasal 4 tentang Pengelolaan Sampah.

Peraturan Daerah Kota Tarakan No. 5 Tahun 2014 Pasal 39 tentang Pengelolaan Sampah.

\section{Situs Internet}

https: //id.wikipedia.org/wiki/kotatarakan/ penduduk. Diakses pada . 13 Januari 2020, Pukul. 19: 00 WIB.

Benuanta, 14 November 2019, diakses pada 10 Februari 2020

Samudranesia, 28 januari 2020, diakses pada 14 februari 2020 
Virioner - Vol. $13 \backslash$ No. $2 \backslash$ Agustus 2021 